\title{
Reclaiming Public Open Space within the Shifting Landscape of Dhaka, Bangladesh
}

\author{
Salma Begum \\ OSA Research Group Urbanism and Architecture, Department of Architecture, Faculty of Engineering Science, KU Leuven, \\ 3000 Leuven, Belgium
}

Received July 22, 2020; Revised October 25, 2020; Accepted November 3, 2020

\section{Cite This Paper in the following Citation Styles}

(a): [1] Salma Begum, "Reclaiming Public Open Space within the Shifting Landscape of Dhaka, Bangladesh," Civil Engineering and Architecture, Vol. 8, No. 6, pp. 1178 - 1193, 2020. DOI: 10.13189/cea.2020.080603.

(b): Salma Begum (2020). Reclaiming Public Open Space within the Shifting Landscape of Dhaka, Bangladesh. Civil Engineering and Architecture, 8(6), 1178 - 1193. DOI: 10.13189/cea.2020.080603.

Copyright $\bigcirc 2020$ by authors, all rights reserved. Authors agree that this article remains permanently open access under the terms of the Creative Commons Attribution License 4.0 International License

\begin{abstract}
Public open space is an essential structuring landscape element and is a pivotal point for the civic social system in a city. Unplanned urbanization and densification are often deemed responsible for the disappearance of public open spaces in Dhaka. Since 1960, as one of the fastest-growing megacities, Dhaka faces continuous destruction of open spaces that includes seven vulnerabilities: water, riparian areas, parks, vacant lands, green areas, greenways, and ecological reserves. To ensure sustainable growth along with proper functioning of ecosystems, foster social cohesion and public health, there is an urgent need to assess shifts in Dhaka's landscape - by re-evaluating the interaction between Dhaka's Public space and the urbanization of its natural landscape. Therefore, this article explores historical avenues of Dhaka's natural-urban metamorphosis through urban mapping and cartographic exploration to understand the transformation of public open spaces over time. This way, the aim is to identify future potentials for preserving nature and strengthening the role of public open space and its manifold uses through unfolding the hidden layers of history.
\end{abstract}

Keywords Public Open Space, Urbanization, Landscape, Sustainable Development

\section{Introduction}

Cities are composed of multiple layers of history - partly hidden, partly visible in their current urban form. Each of those layers is the result of a continuous transformation of five critical elements: environment, culture, society, ecology, and economy. The city represents a constellation of these elements in an active network. Failure in one element collapses a city as an active entity. One significant element of this city is - public open space, often closely related to native landscape, characterized by two key natural features - water and green. [10]. These elements are dynamic in nature and changes, re-structures, re-produces over time. In the process of re-structuring, this shapes the urban form, behavior of habitats and people. The city is administered by two factors: tangible and intangible. Tangible refers to ecology, and intangible means the economy, politics, and society. Very often the tangible factor is neglected in the formation of the city, despite being the major structuring element. Dhaka is no exception to this. Despite being in the world's largest delta, since 1960, the city had indiscriminately developed disregarding the logic of nature in the pretext of urbanization. Current practices of Urbanism and Urban planning do not seem to pay much attention to the natural landscape in general. As a result, the city's public open spaces are experiencing challenges to endure as a socio-ecological ground. Due to unplanned growth of urban landscape over natural landscape - tensions and conflict arise from the stark difference between the availability and need for qualitative open space. These conflicts are tightly bound up with the disappearance and mismanagement of landscape elements such as parks, forests, water bodies, canals, civic spaces. These spaces are not only disappearing but also losing their identity and deprived of being space as a public resource. Although the 
city is surrounded by rivers on four sides - Dhaka has failed to behave and develop as a deltaic city. The water bodies are largely disconnected to be precise; the peripheral rivers are disintegrated with the inland waterways. Once it was recognized as the "Venice of the East" for its interconnected water system, now barely holding its waterways. Dhaka appears more like an island (Fig 1) rather than a genuine water city - turning its back to its abundant waters rather than acknowledging them as fundamental natural resources and overarching landscape systems - that inevitably structure the urban and urbanization territory. To envision more sustainable future interplays between landscape and city, a closer understanding of the logic underpinning natural water systems in relation to the city and its manifold urban spaces are necessary. Unfolding this continuous interplay across historical layers could help to understand the logic for both the prosperity and perils of Dhaka as this is connected to the fading ecology.

Dhaka, the capital of Bangladesh, is home to over 15 million people [3]. Ranked as the 9th largest city in the world by population, it continually experiences the destruction of open space. The city is situated on the uplifted terrace of the Madhupur tract which is a part of the Bengal Basin. Dhaka has a glorious past as Eastern Bengal in both periods: the Mughal and Pakistan. Present Bangladesh is the successor of Eastern Bengal, and together with western Bengal comprises the Bengal Delta. Till now, most of the debates on Dhaka's history lack the broader ecological significance through which numerous stages of Dhaka emerged [13].

The bustling-hustling modern megacity Dhaka, for long time, was a constellation of villages [19] during pre-Mughal period, scattered across, and largely dominated by the natural landscape along the north bank of the Buriganga River. Dhaka came into prominence as capital several times during Mughal period [18]. In 1610, with the shift of the capital from Rajmahal to Dhaka by the Mughal Governor of Bengal - Islam Khan Chisti - the Mughal fort or Territory of Dhaka was born. In 1660, it was again reinstated as the capital of Bengal after a brief change by Mughal Emperor Shahjahan in 1639. Thus, over the centuries, the capital of Bengal changed several times. But one noticeable thing was - in every case, all the capitals were built on the levee (Fig 5a), as they were heavily depended on the extensive inland water transport system of the Ganges delta and the freshwater supply. The emergence of the city was structurally contingent on the vast water system of the delta.

Therefore, the hypothesis is - if the navigability of rivers constituted the reason for capital shifting and water was the major reason for settlement - then how did the water system structure the urbanization pattern - in the past and in the present? Additionally, this research also investigates how the interplay among natural landscapes, built form \& public open spaces was shaped by social behavior under the political regime? The aim is to explore the evolutionary layering of shifting landscape and its role in making public open space in different eras. For that, interpretative mapping and cartography would be developed as an analytical tool, based on historical evidence that includes different media such as maps, sketches, text, photographs, and video documentation. Through analysis, this study tries to address the gap in the literature on Bengal, from an ecological perspective within the historical discourse.

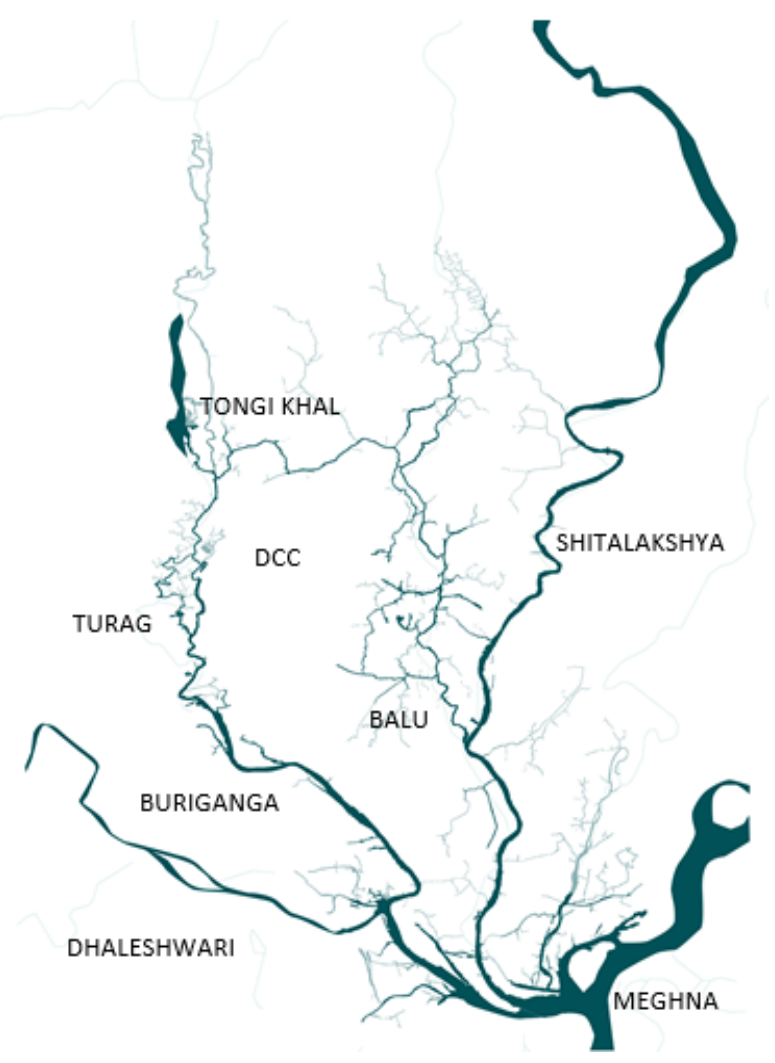

Figure 1. Dhaka city corporation area (DCC) as an Island bordered by three rivers and one canal on the North (Developed by Author

\section{Materials and Methods}

This study follows a multidisciplinary approach that combines geography, urbanism, and architecture to understand the complex layering of the shifting landscape. The research starts with a cross-scale analysis by zooming in and out to explore the interface of land-water in relation to the settlement and public space of Dhaka. A contextual inquiry is done using GIS data 2010-2015 and Goggle Earth Pro. Historical data were mapped through urban analysis by interpretative mapping and cartographic exploration. Therefore, the maps and discussion in this article are solely based on literature review, analysis of archival maps, GIS data, and historical photographs. The urban analysis includes de-coding and re-coding data, translation of texts into mapping, re-mapping of water, territories, and public open spaces as a dynamic layering of 
the historical process as a part of an atlas construction. This article is a part of an on-going Doctoral research that tries to formulate an atlas that reimagines the water networks, as both hybrid and dynamic structuring elements of the city. Hybrid here means the maps merge diversified narratives, typologies, and spatial categories such as marshland, river, canal, and tissue from different periods of the same century. The Dynamic quality integrates the historical evolution of the watercourse and its shifting interrelations with the settlement over time.

\section{Discussion}

\subsection{Geographical Context and Ecology of Bengal Delta}

During the past seven hundred years, under several political regimes, the ecology of Bengal has undergone multiple changes in terms of physicality and functionality, where water was the core of physical structure and green was the core of the functional structure. The complex political interventions from different era resulted in the deterioration of the East Bengal's ecology, more specifically the disappearance of the core elements - water and forest. This change of ecology triggered several other changes on micro-level structuring of social open space. Therefore, an understanding of plain's ecology is significant to any social and political changes of territory and city.

The history of the Bengal Delta from an ecological perspective portrays the intricate river system dominated by three main rivers: the Ganges, the Brahmaputra, and the Meghna as the key feature of the landscape. These rivers carry the world's largest sediment load [1] from the Himalayas and channel into the Bay of Bengal and form the largest Delta in the world. In the process of disposing into the Bay of Bengal, this silt carrying rivers creates enormous areas of new land. This formation of new land is always in the making by a mutual confrontation of silt-carrying rivers and the sand-carrying sea - known as a double process [12]. In the past, this process formed the current Bengal Basin, which is largely occupied by Bangladesh (Fig 2). Physically, this basin is a flat, low-lying floodplain surrounded by disconnected hill systems on three sides except for south, constituting four types of lands: Comilla Terrace of the Holocene, Tertiary Highlands, The Barinds, and Madhupur Tracts as uplifted deposits of the Pleistocene [1].

The major fluvial source of this basin is The Ganges, Brahmaputra, and Meghna. Although, ecology was central to the mainstream political and social economy during colonial period, it was always out of the discussion in historical discourse from an ecological perspective. This study examines the changing relationships within three elements of a settlement throughout history: natural landscape, city, and public open space embedded within ecology, economy, and society. The whole discourse of this changing scenario is explained under two broad issues: the changing ecological process of Bengal Delta and politics and policies subjecting to ecology and rural economy along with ecological resources in making social spaces.

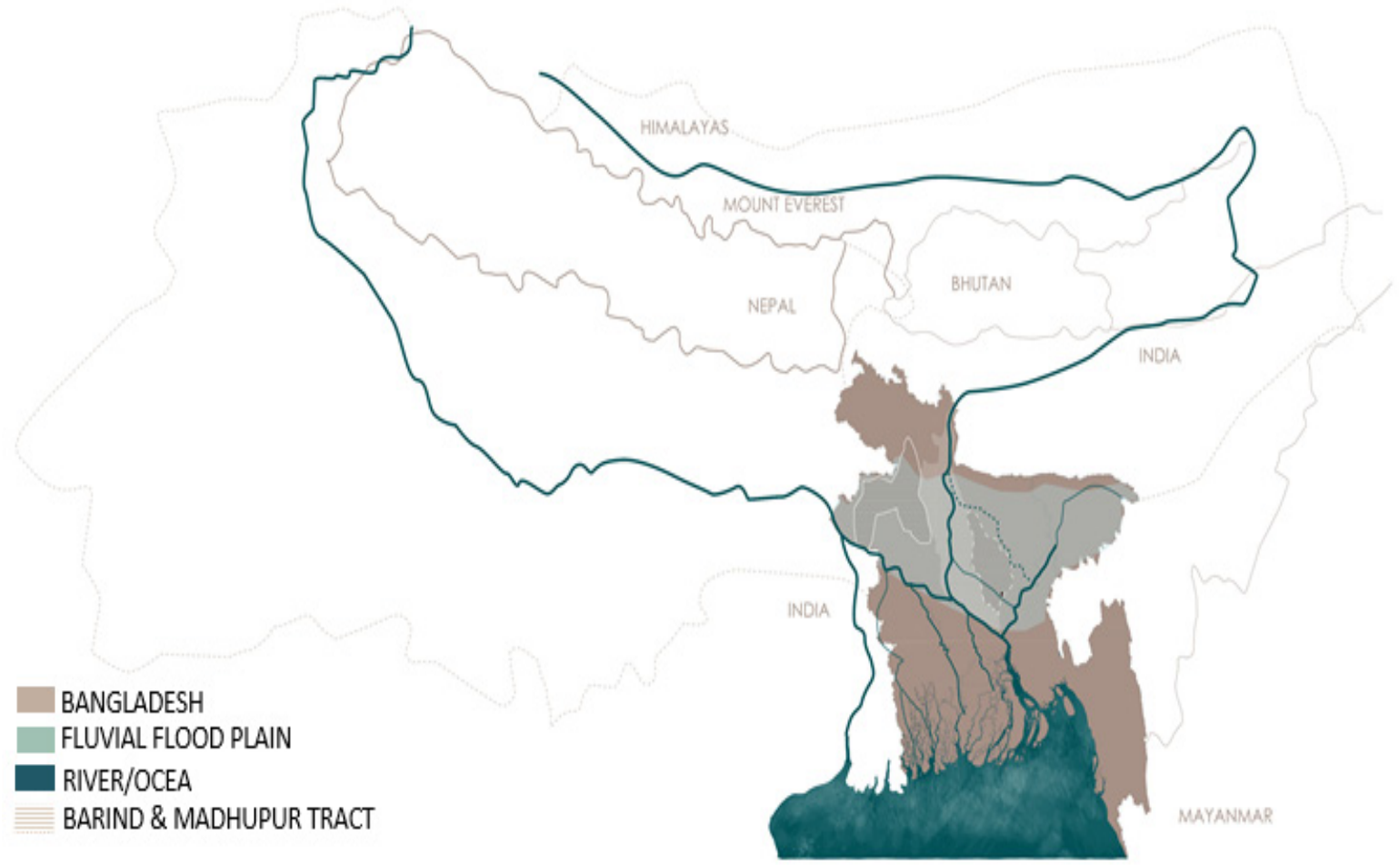

Figure 2. The geological settings of Bengal Delta, the Himalayas and major river system (Developed by Author) 


\subsection{Unfolding Ecology and Land Formation in Bengal Delta}

Today's Bengal delta and its deltaic floodplain have primarily been influenced [17] and shaped by three major river systems: the Ganges, Brahmaputra, and Meghna. Additionally, the three-river system is the key determinant of the wetland ecosystem [17] within the GangesBrahmaputra-Meghna (GBM) River Delta. Being bordered by the Bay of Bengal to the south and Himalayas to the north - Bengal delta had been appearing in many forms and characters throughout the history - staging as a frontier region in the Indian Subcontinent. Due to its location, it had played a significant role for a long time in international trade under the imperial power [12]. The remarkable position brought attention to European traders to settle on this land that convoyed amalgamation of various ethnicity. This concoction of ethnicity shaped the culture to hold positions as both regional as well as cosmopolitan. Moreover, this also induced a different cultural landscape that is profoundly integrated with water.

This cosmopolitan yet Bengali region had re-formed, re-sculpted, re-surfaced in new shapes in different periods by constant alteration of the major rivers (Figure 3a). Two major river systems were largely responsible for shaping the Bengal Delta: The Ganges $(G)$ and the Brahmaputra (B). The gradual movement of Ganges from west to east (Fig $3 \mathrm{a} \& 3 \mathrm{~b}$ ) and the west to east movement of Brahmaputra (Fig 3b \& 3c) - known as Brahmaputra avulsion - triggered the gradual increase of land in eastern Bengal, and therefore, Dhaka. The present Dhaka is of central to Bengal basin, came into being within the constant shifts of river and landmass. The consequence of this alteration of rivers had a positive impact on the eastern Bengal as it was receiving more flows from Ganges-Padma system. This established direct river communication with North India, reducing transport cost from East Bengali as well as receiving direct siltation from the Ganges, making the area more fluvial, and intensifying the cultivation area along large rivers [9]. Thus, the changes in river course transformed the land formation and integrated the geographic, politics and economy of eastern Bengal to the Mughal Territory and beyond.

However, the completeness of today's Delta triggered by a subtle shifting of Ganges and Brahmaputra, can also be traced back in all the primeval maps, among which the maps of 1548 by Gastaldi, 1554 by Giovanni, 1615 by de Barros, 1660 by van den Broecke and 1779 by Rennell bear the testimony. In around $16^{\text {th }}$ Century, the Ganges started to move eastwards (Fig 3a ii), resulting the formation of two branches - one going to Satgaon/ Hooghly (Ougely) and another towards Sonargaon/Dhaka (Dacca). This shift ended at the meeting point with the Brahmaputra after avulsion around 1830 (Fig 3a iv). The reason behind the shift was partly due to the land uplifting of north-western Bengal along with subsiding of the Bengal basin, including eastward tilting and partly due to the monsoon flood difference. A theory from 1861 indicates that when Ganga was at its highest pick, Brahmaputra already had the flood a month sooner which provided a natural vent for Ganga to flow south-east. Another major incident from the last century was the Brahmaputra avulsion that started after 1770 - as mentioned by Sarker (2009) cited in Akter et al. [1] - and took more than 50 years to complete, until 1830 (Fig 3 iv-3 vi). This avulsion (Fig 3c) was caused by the tilting of Madhupur Tract, subsidence of Sylhet Basin and the massive flood in 1782 [1]. The new river course appeared as wider, identified as Jamuna river (Fig 3c) and eventually intersected with the Ganges (Fig 3a vi). Previously, these rivers had their separate streams and banks, confluence directly into the Bay of Bengal. But after the avulsion, both rivers conjoined together (Fig 3a vi) in the west of Dhaka, approximately $200 \mathrm{~km}$ from the Bay of Bengal, and from this point, as one narrow downstream named Padma river - previously known as Kirtinasha River(Fig 5a) - found in 1840 map by SOAS, conjoined to Meghna River which is more than $100 \mathrm{~km}$ long before reaching the Bay of Bengal. This macro-scale changes in the river system caused several other changes in the micro-scale river system. According to Taylor (1840), Rennell's map indicates that, before avulsion, Dhaleswari was a distributary of the Ganges and Buriganga was a distributary of Dhaleshwari but after avulsion, Dhaleswari became the major distributary of the new Brahmaputra, which is Jamuna [14] and conjoined with Buriganga near Narayangang. The whole process is a matrix of the interplay between land and river across different scale. According to Tilley (1997), a landscape is a set of few other subsets that include a series of selected sites and places connected by path, movements, and narratives [24]. Therefore, the Bengal delta can be depicted as a fluid landscape that is a set of series of locales and places formed by the movements and shifts in river course related to the narrative. 

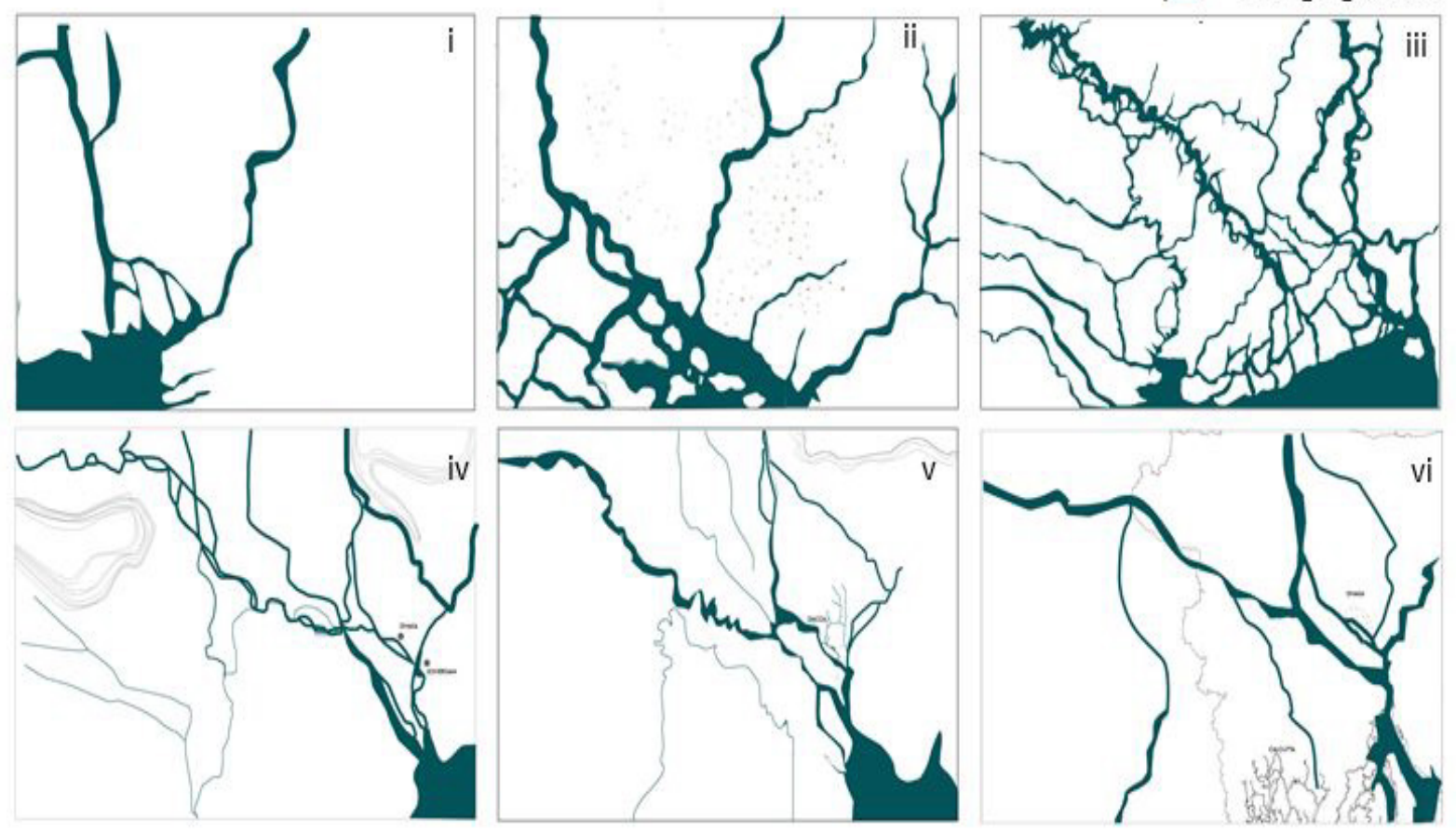

Figure 3a. Ecological change and land formation in Bengal Basin (i) 16th century; (ii) early 17th century (iii) mid-17th century (iv) 18thcentury (v) 19th century (vi) 20th century (Developed by Author)

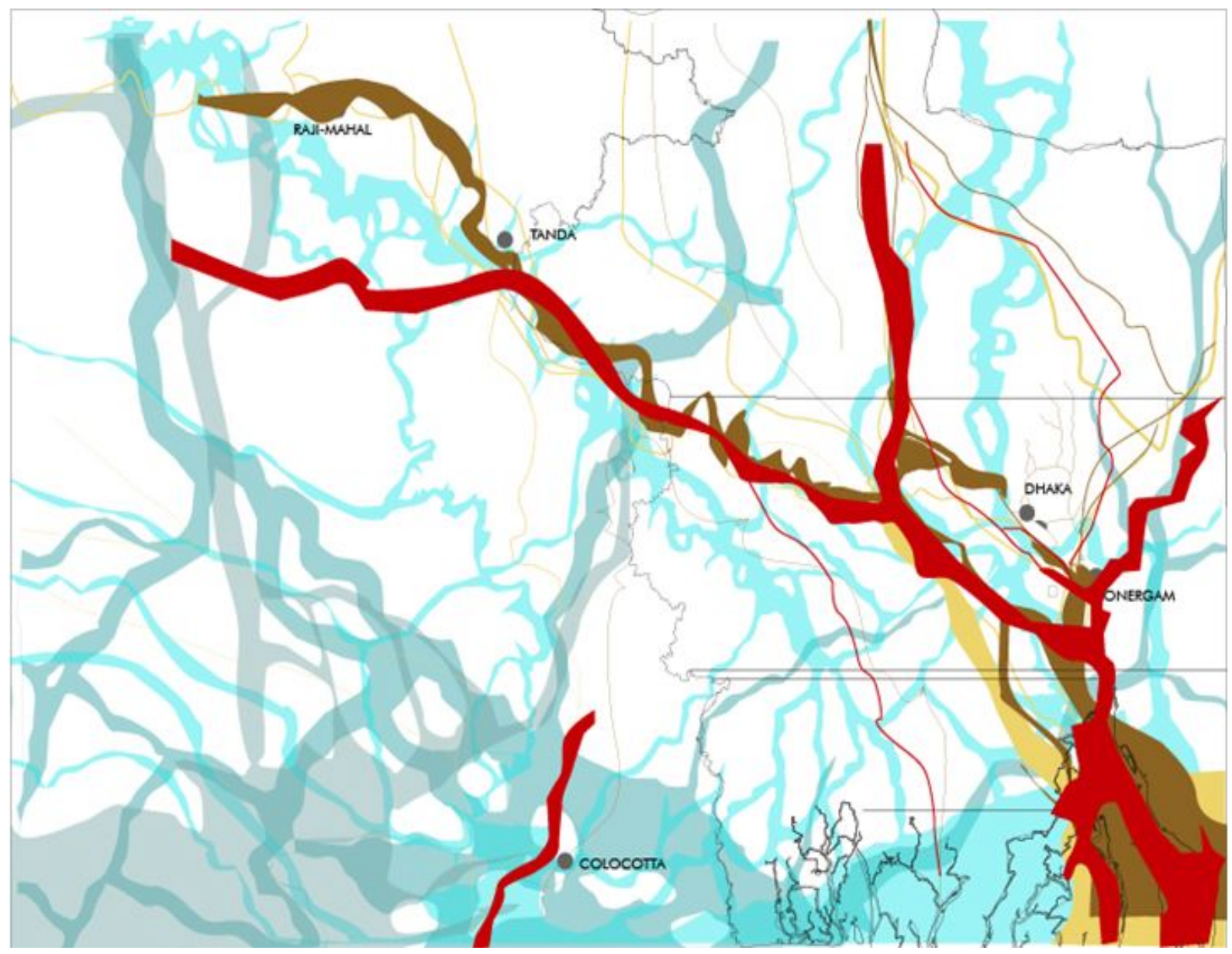

Figure 3b. Shits of river course from 16th century to 20th century (Developed by Author) 


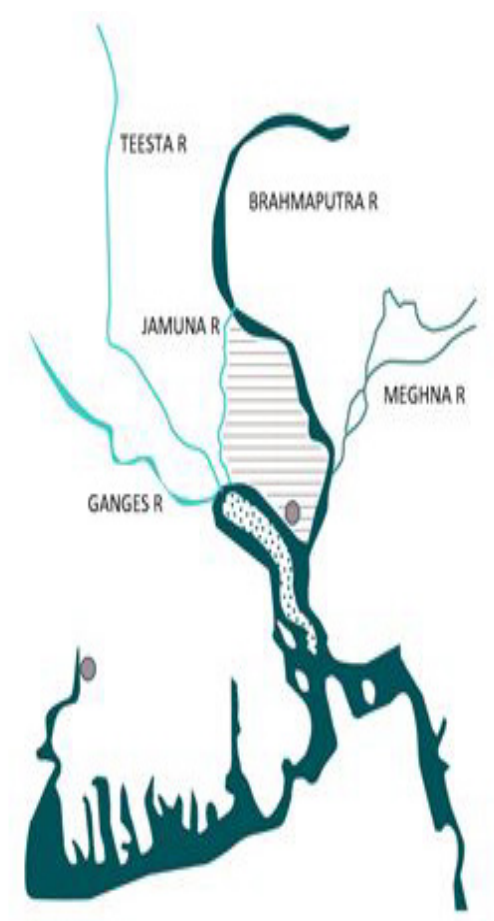

1767-RENNEL

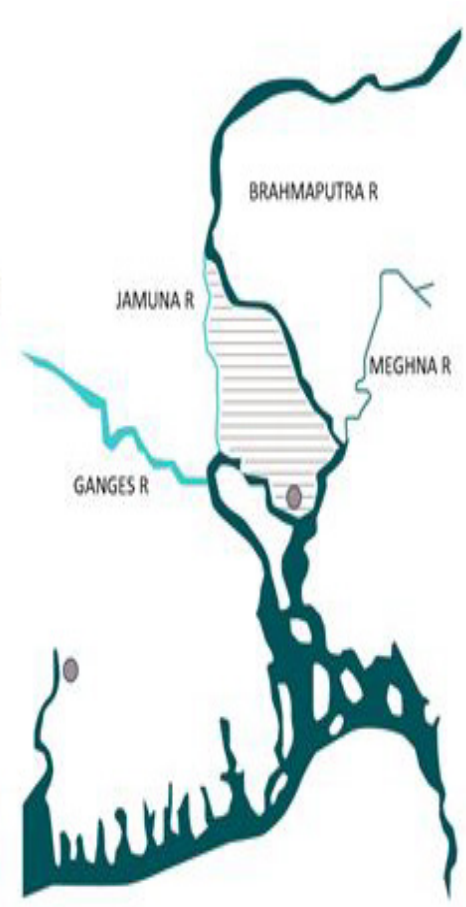

1821-1834 RENNEL

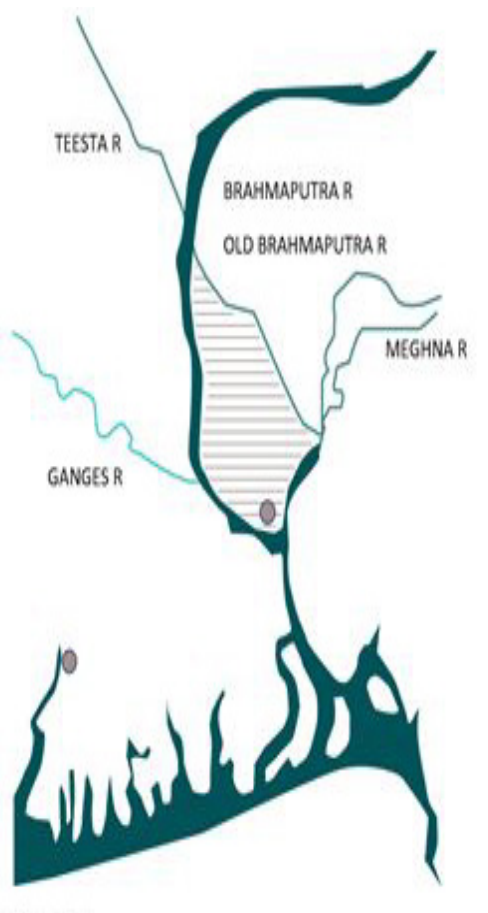

1991 ISPAN

DHAKA AND Calcutta

Figure 3c. Shifts of Brahmaputra from 1767 to 1991 (Developed by author)

\subsection{Development of Dhaka from Ecological Perspective}

Taylor (as cited in Iqbal, 2013) describes the location of Dhaka:

The city stands upon the northern bank of the Boorigonga [Buriganga], about eight miles above its confluence with the Dullaserry [Dhaleswari]. The river, which is here deep and navigable, by large boats, expands in the season of inundation to a considerable breadth, and gives to Dacca with its minarates and spacious buildings, the appearance, like that of Venice in the west, of a city rising from the surface of the water. (Taylor, as cited in Iqbal, 2013, p.45)

From the above description, Dhaka's position seems to be geographically well located in terms of communication; also a commanding [22] position in terms of navigability as well as centrality. So, the dynamics of present Dhaka in a historical process could better be appreciated from an ecological perspective.

The Dhaka city has emerged, flourished, declined and re-surfaced, as a river-based trade center, a garden city on water from Buddhist period to the present day no less than five times in the past 2,500 years in five different sites (Fig 5a) - Savar, [20] Wari-Bateshwar, Vikrampur, Sonargaon, and the present-day settings [13].

All the settlements indicate a similarity in terms of geographical settings, locating in between two major rivers - either as an island or a patch. This indicates that river has mostly been the determining factor of present Dhaka city's development and establishing settlements since the era of the Maurya dynasty in 450BC until 1960.

Nevertheless, the present Dhaka city was linked to nearby other two settlements: Sonargaon and Vikrampur by river and waterways (Fig 5a). Fluvial waterbody as rivers, inland water bodies as lake and canals, and Open water body - Marshy and Peaty inundated Low-lying land on floodplains are the ecological features. Another important feature of this region that made this a preferred location is the vegetation and Forest (Fig 5b). The etymology of the word Dhaka originates from Dehaka Iserry as Dehaka [8], then Dacca followed by Dhaka from the revelation of a deity/temple in a Jungle (Fig 5a and 5b) near waterbody that is currently tiled as Dhakeshwari Mandir. This was triggered in the $7^{\text {th }}$ century by Bollalsein during Adisur dynasty under Buddhist period which represented the forested ecology of the area.

Due to its geographic centrality and well-off river-canal communication system, this attained a prominent role in 1610 by becoming the new capital of Bengal. Even though historically, mostly the capital of Bengal was on the northwest part of the country on the Ganges, but due to the change in the river course, the navigability changed, and the capital moved to the east of Bengal. There are three key reasons behind the shifts of capital except for the change in the river course: strategic, economic, and ruling impulse. Dhaka is hundred miles above the mouth of Ganges and 
eight miles above the confluence of Buriganga and Dhaleshwari connected to Padma, Brahmaputra, and Meghna by waterways, making it convenient to get in and out easily from the sea, thus inviting merchants from Europe, China and other parts of the world (Fig 4). It was also well located in terms of land communication, being on the highest level in comparison to the inundated area by surrounding rivers in an ordinary season. This highland was flanked on both sides by the riverbeds as well as with marshlands which sometimes creeps in inside the highland made the present-day city dwellers life difficult due to the inundation and flood happened owing to the denial of natural logic during urbanization.

Islam, et.al. [14] describe "Dhaka was under a thin deciduous forest and scrub jungle" and the farmers were mostly dependent on nearby natural vegetation for their daily supplies (Fig $5 b \quad \&$ 6) [14]. According to the European travel document and as well as Ain-i-Akbari (as cited in Islam et al., 2010) Dhaka was comprised of extensive forest, mostly in the northern part and scattered in the elevated drier central areas predominantly contained with 'Sal 'trees (Fig 5b \& 6) in the upper canopy [14]. According to Francois Bernier (as cited in Islam et al., 2010) a great amount of area was highly fertile, so the people cultivated silk, cotton, and many other essentials along with rice, corn, etc [14]. Dhaka gained its prominence due to the production of silk, specifically for 'Muslin'.

From many of its locality names such as Katabon, Segunbagicha, Dhanmondi ${ }^{2}$ (Fig 7 shown as paddy field), it is evident that different varieties of plants, trees, and crops were major production on this land.

Dhaka, home to about 37 Indigo houses, was also a major outlet for the Bengal Indigo export to Europe, stated by Taylor (1840) also featured its forested ecology [23]. Dhaka - as the last phase of the sequence of river-based settlements - is a part of the reincarnation of one metropolis indicates the same ecological features and geostrategic locations in Bengal Delta as of other three regions: Wari-Bateswar, Vikrampur, and Sonargaon.

\footnotetext{
1 Muslin obtained from a unique variety of Karpas Tula or Phuti Karpas scientifically known as Gossypium herbacsum used to be grown in Dhaka (Kapasia, Tok, Sonargaon and Janglabari). This sort of trees needs specific climatic (temperature, humidity, rainfall, sunlight) and geographical (near riverbanks) locations to grow.

2 Katabon is Thorny plants as Bon Boroi scientifically known as Ziziphus onenoplea.Most of the Dhaka University area were under scrub jungle. Remaining deforested areas were for Sungrass locally known as Chhan which was used for the thatching of the roof of the houses noted by Manucci (1663) as cited in Islam,et al., 2010. Dhanmondi was an expensive rice field extended up to New market and it is also mentioned that a huge "haat" used to take place here where all kind of grain and rice was sold which literally developed the name of Dhanmondi (rice bazaar).
} 


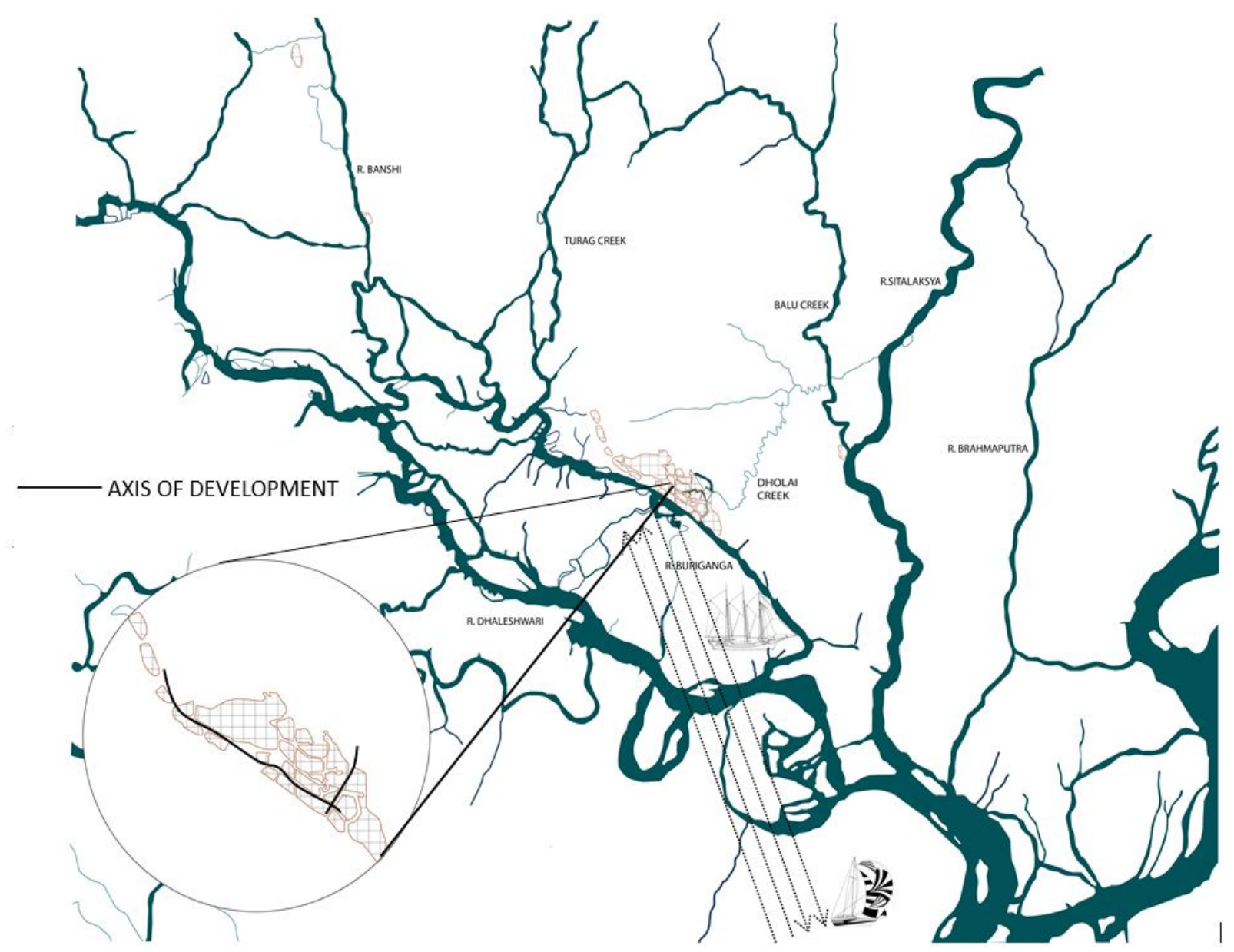

Figure 4. Changing ecology in greater Dhaka in 18th century and shifts of capital to Dhaka (Developed by Author) 


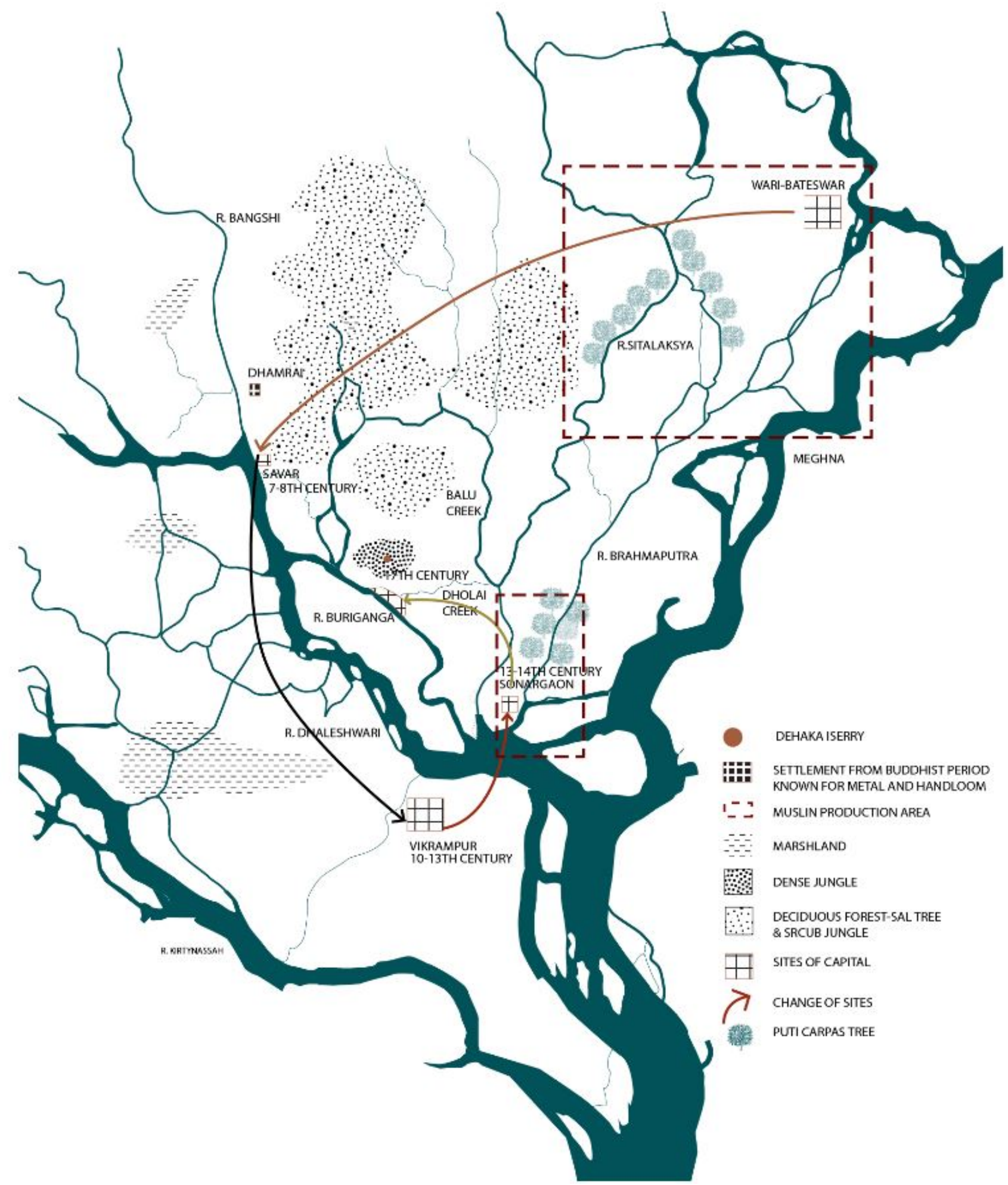

Figure 5a. Changing ecology in greater Dhaka and location of shifting capitals in 19th century (Developed by Author) 


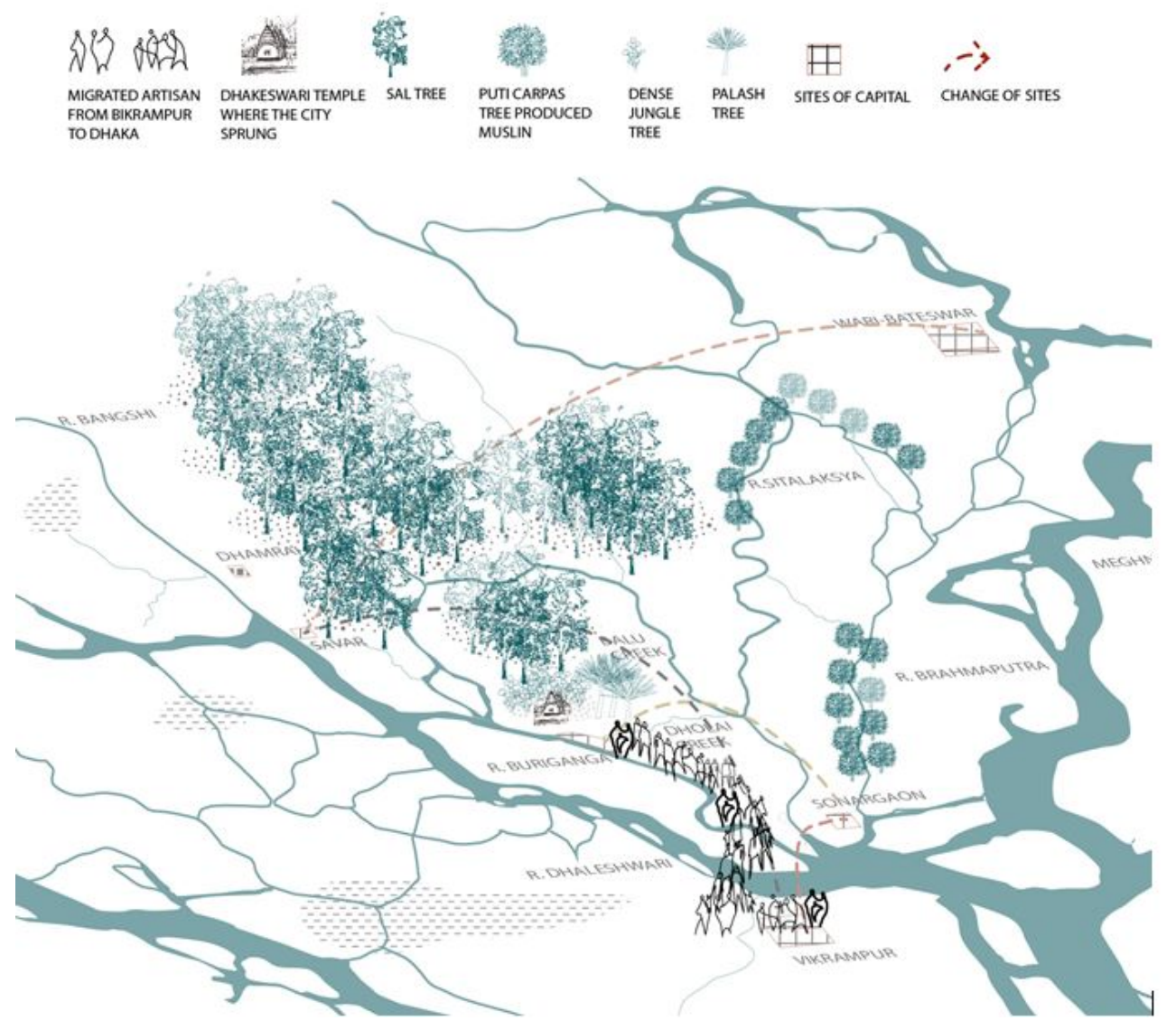

Figure 5b. Changing ecology in greater Dhaka and location of shifting capitals in 19th century (Developed by Author)

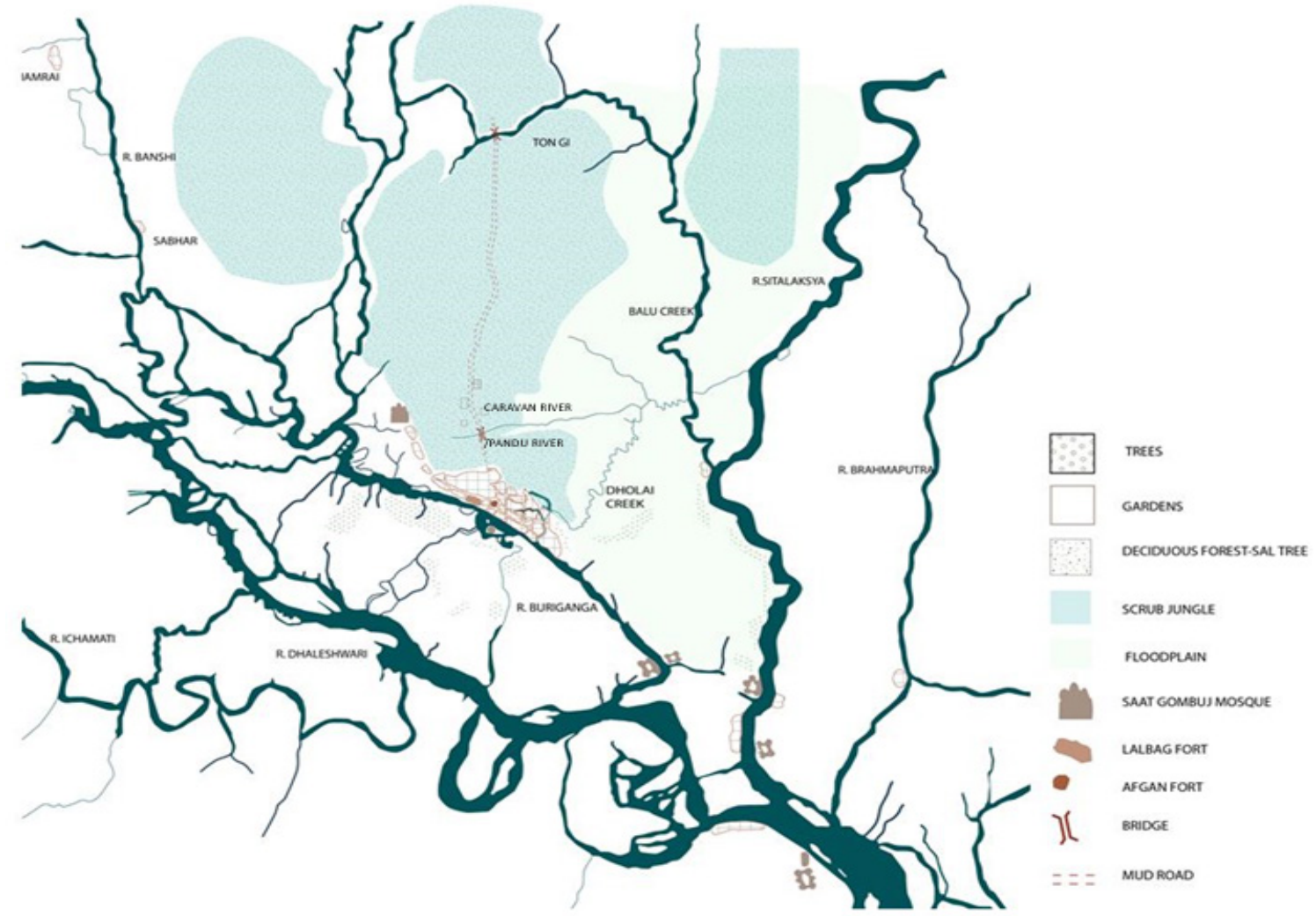

Figure 6. Dynamic layering of Forested ecology and Bengal's Fluid in 18th century (Developed by Author) 


\subsection{Politics and Policies Subjecting to Ecology and Rural Economy}

Natural settings of Dhaka made this the central of Bangladesh and a hub for major economic and industrial power. With the interplay of political and economic power, this has sustained throughout history. Dhaka played the role of Capital in different political regimes - notably two hundred years under Mughal as a Capital of Bengal. Although the city is surrounded by rivers, its unforeseen growth failed to take the city's foundation and nature into account. Thus, it is often seen as a "grey-concrete-jungle". Today's Dhaka is the outcome of a rapid and unplanned urbanization which portrays high rise development in the form of residential, commercial, and mixed, while the old center shows compact highly dense urban tissue.

Since the dawn of this historic city, until 1757, it has been following the logic of topography [4] while emerging as a business hub from a small Hindu trading centre [7]. Dhaka as a manufacturing center of cottage products reached its apogee as a Capital under Mughals. The land became famous for both cottage [16] and agricultural products. According to Fitch as cited in Eaton [9] remarks in 1586 , the best and finest cloth made of Cotton was found in India, mentioned about Sonargaon that is just fifteen-mile east of Dhaka [9]. This period saw the first ecological intervention with the canalization of Dhoali Khal (Fig 7). This canalization safeguarded the city from the enemy and furthered the scope of the area as an activity generating space, rather than just being city sprawl. River and canal being the bloodline of the city were the basis [2] of city sprawl.

The early Dhaka emerged along the course of Buriganga (Fig 7), following the old levee [6] in the east-west direction [21] as well as the streets. The city elongated in the east-west direction partly for the people wanting to have their houses near river [14]. The two major roads formed the city axis to develop, running parallel and perpendicular to the river. Both roads converged in Victoria Park connecting the business district in Tejgaon in the north and the fringe on the west (Fig 7). This historic core formed the active civic spaces at the junction of the streets on an intimate scale [11]. Where small nodes acted as small public spaces the Chawks and Bazzars were the large-scale public squares and Market place used mainly for commercial purposes. The Chawk Bazzar was the central gathering space which was a link to water transport. This period is also attributed to the creation of two types of gardens - encampment and pleasure: inside and outside historic city respectively known as Aurangabad (present name Lalbagh) Fort garden and Bagh-e-Badshahi (present name Ramna). Additionally, garden houses outside the city core near Carevan River (Fig 6) were developed by European traders [5]. Most of the developments of this period were situated on the higher ground.

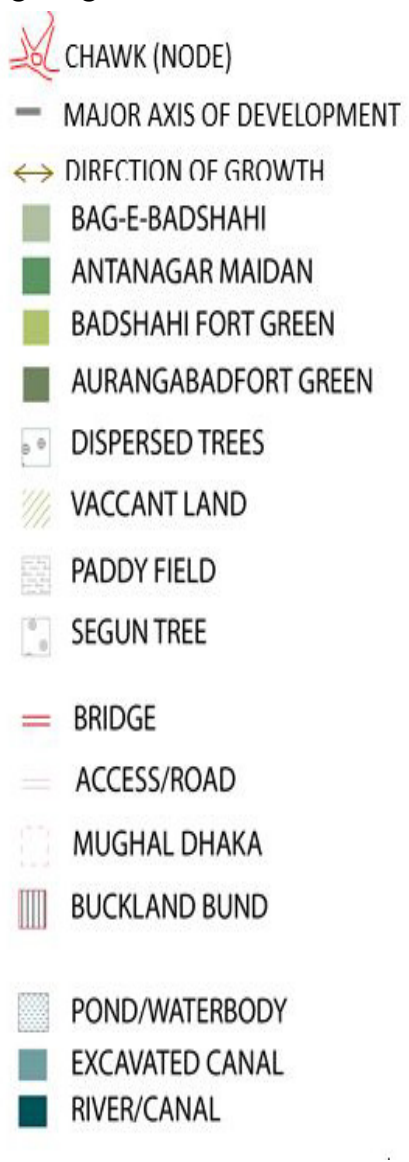

Figure 7. The new Capital of Bengal Subah with natural and man-made landscape in 19th century (Developed by Author) 
The expansion continued to develop along the ecological corridor until the British took off the power and started leaving colonial imprints in the ploy of modernization. After taking over the control of Dhaka in 1757, EIC developed the city as a regional trading centre and market. E.I.C levied four major policies to suppress the Bengal Muslin Industry: imposing high taxation on local Muslin thread, importing machine-made Muslin from Britain in low price, destroying white (Phuti) Corpus cotton trees of Muslin threads, and torturing weavers to stop weaving and passing knowledge.

As a policy to rule over the local market, the British had introduced the land revenue system in 1793 as well as implemented $80 \%$ taxes on domestic handmade Muslin. Their systematic political decisions destroyed the local industry and economy. As early as 1817 , by introducing imported English mill-made thread, the city started facing the fall of handmade thread and muslin production. This has favored the British economy by exporting machine manufactured textile to Bengal. To stop the production of Bengal Muslin, all the white (Phuti) Corpus cotton trees were destroyed, and thumbs and tongue of the weavers were cut off as noted by a William Bolts in 1772. Colonial policies impacted the local Muslin production heavily and in two centuries, it had lost its quality and excellence as the finest Muslin in the world. The loss of Muslin production took away the significance of riverbanks as a means of settlement and economy as all the plants were grown along the riverbanks only - mostly on Sitalakhya (Fig 5a \& 5b) and Brahmaputra near Dhaka. But as a capital, the city still held its importance due to its commercial prospect.

Nonetheless, the significance of rivers and canals as a vital means of transportation and communication was declining by the advent of land transportations. Until colonial period, boats were the main mode of communication, accessed through the intricate network of canals that started to disappear with the growth of new Dhaka as the capital of Eastern Bengal and Assam after 1905. However, two changes were interesting to look at in this process of urban taking over the natural landscape were the creation of ponds and excavation of lakes (Fig 7-9). The canals were excavated to manage the wastewater discharge and stormwater drainage while the ponds were excavated to dig out the earth for building huts in the surrounding areas.

Nevertheless, from 1939 to 1997, this new type of pond morphology declined from 379 to 285 [14] during the process of development of the new Capital along with the reduction of several other water bodies such as marshes, and swamps - being filled up to make room for new urban infrastructure. Apart from filling up of the water bodies, conversion of vacant areas to gardens from 1859 to 1924 (Fig 7-9) was a noticeable feature of colonial morphology. Other major changes that had strong imprint in physical environment is the development of civil line and the birth of the railway in 1846 in the whole Bengal favoring land communication in the so-called modern planning. In Dhaka, it took until 1880 for historic changes to be realized via modernization with the new infrastructure - railway and embankment. The railway connected the $18 \mathrm{~km}$-distant river port of Narayangang and other parts of the region. The axis of development from 1779 (Fig 4) became the civil line in 1859 (Fig 7-9) which along with railway brought fundamental structuring in Dhaka's layout.

As a result, the city started to behold the complementing relationship between river and land-based infrastructure development. Apart from this shift, the railway (Fig 7) heralded two major shifts in the region - industrial and agricultural. As early as 1864, a dike to prevent and protect the settlement from flood [4] and erosion was built. Additionally, according to D'Óyly (as cited by Rahman \& Ara, 2016) remarks in 1814, a lot of canals were abandoned and unnavigable [21] due to lack of maintenance by the end of the late 18th century. Precipitously, a city of 40 canals was transformed into a city of infrastructure (Fig 9). Moreover, the introduction of metaled road, pipe, [18] and automobile, river and water body completely lost its commercial importance. This way the city turned its back to the river - losing its both importance economic and social importance while shifting towards land. 

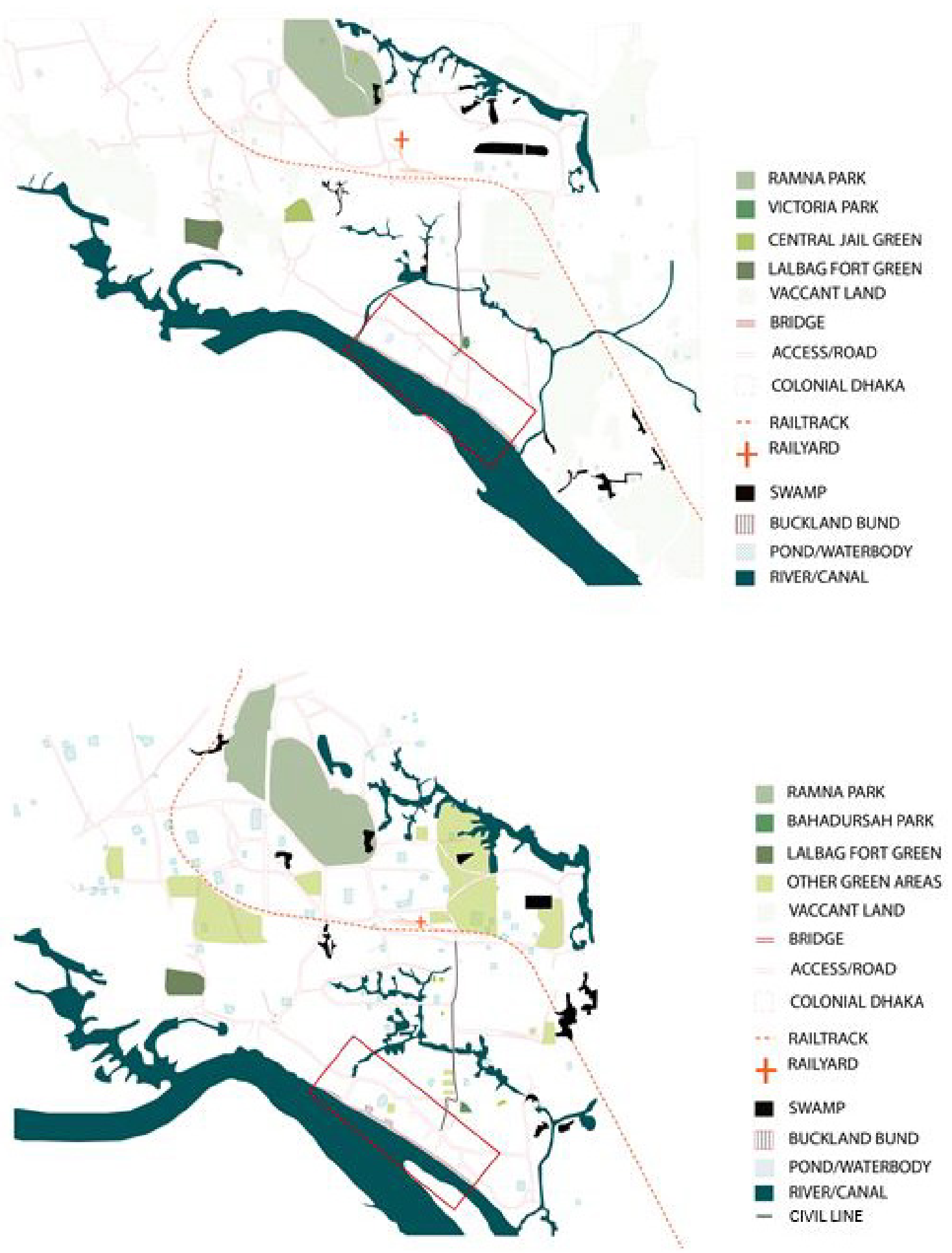

Figure 8. Implementation of Railway, declining water-based commuting, and man-made intervention as public open space in 20th century (Developed by Author)

In the continuation of the process, the city started expanding through ecological transformation via deforestation and filling up wetlands [15]. However, modernizing Dhaka saw a new definition and use of social space with the construction of the embankment along with promenade. The first formal public space appeared with a dyke (Fig 8) as a promenade as public open space. Public space sitting atop of the border between water and city. From 1947 onwards, post-partition Dhaka experienced quite a different destiny with FMP (First Master Plan). Few of FMP policies encouraged illegal encroachment of water bodies and canal that devalued ecological importance. 
Post-colonial Dhaka - known as Capital of East Pakistan could not put ecology into practice. Post-Independent Dhaka did not change much until 2009 due to the absence of a detailed area plan by RAJUK, allowing the city to grow unplanned. Pushing the city growth to the north without considering the river, left it just with peripheral border.

The changing political and Socio-economic conditions were responsible for the change of ecology and urban settlement in Dhaka. Within these changing politics and policy shifts, it is evident that from the Mughal regime to present Dhaka, the open spaces in the form of a river, waterbody, forest, parks, gardens, and social space experienced very different interpretation of ecological values (Fig 10). Whilst the Mughals invited the water inside the city as a blessing by integrating new canals with river via canalization for the use of water as a means of activity, the British refuted the water over land, turning away from the water.

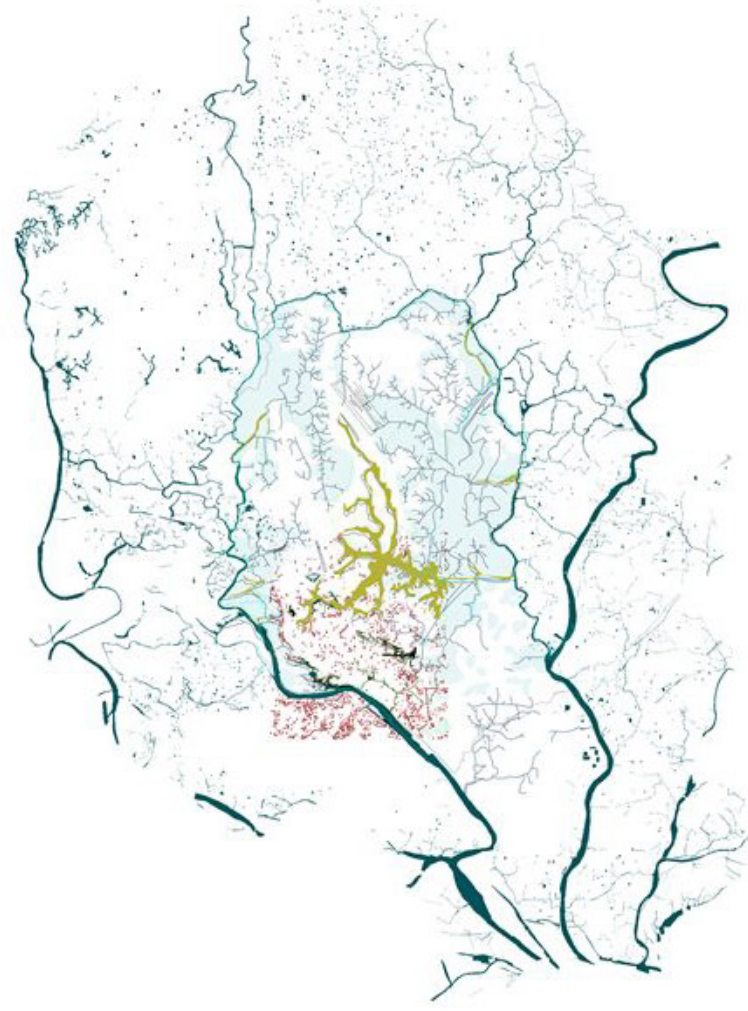

(a)

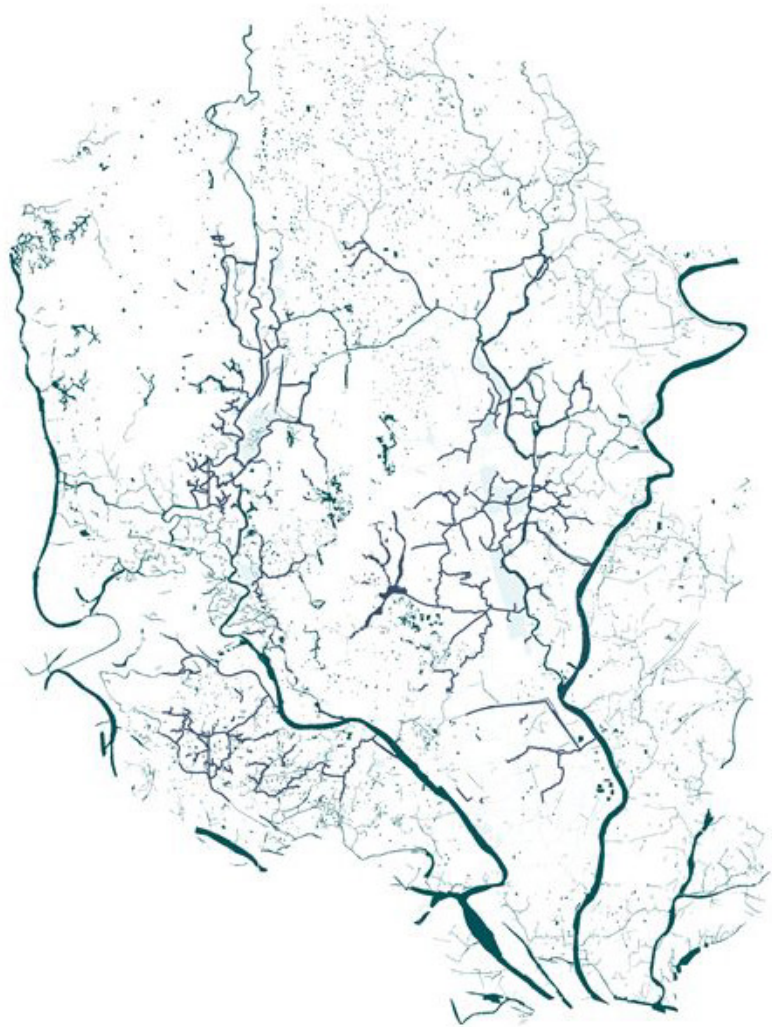

(b) 1924 WATERBody $\square$ 1960 WATERBody $\square$ 1990 WATERBody $\square$ CANAL 1978- 2020 $\square$ RIVER $2020 \square$ WetLAND

Figure 9. Loss of water bodies, wetlands, and canal from 1924 to 2020 (a) 20th century water map (b) 21st century water map (Developed by Author) 


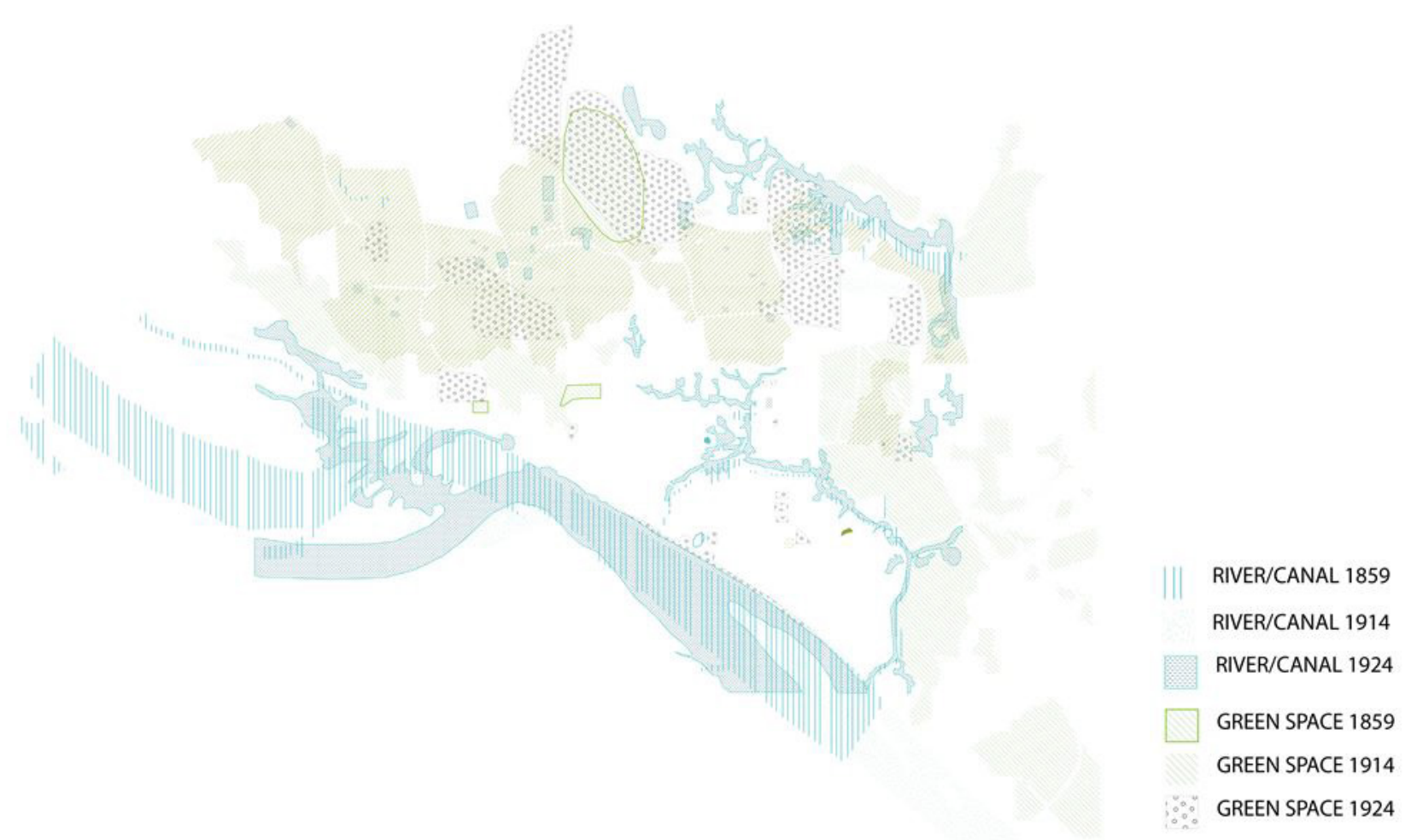

Figure 10. Mapping the Shifting landscape of Dhaka (Developed by Author)

\section{Conclusion}

The prosperity of a city is closely trussed up with its hidden history. To envision a sustainable future for any city, understanding its core value is crucial. Therefore, for Dhaka to be envisioned as a sustainable urban landscape needs an understanding from an ecological perspective that addresses the hydrological system in which this is embedded. Although the city was born from the River Buriganga, yet the city ignored the reality of being part of the most dynamic hydrological system of Bengal Delta by turning its back to the river. Moreover, the city seems to deny its prospect as a deltaic city which does not necessarily portray a picturesque landscape but shows a way to live with water bringing completeness by ecology, economy, culture, and communication. City is a narrative of multiple experiences gained through the interplay between built form and open spaces within a fluid landscape. As a Bengali city yet to be modern, Dhaka needs a radical reclamation of public open space within this shifting landscape. Without the discourse on the relevance of Dhaka being a part of Bengal delta and its evolution, this reclamation would be incomplete. Thus, this article unfolded the shifting chronology of Bengal delta through understanding the matrix of the rivers and the city within history. Additionally, this also focused on how the ecology of Bengal delta influenced society and how the ecology was influenced or shaped by the societal change through politics and the economy. Nonetheless, through unfolding the historical layers, this tries to place Dhaka within this shifting dialogue with the river to assess possible solution that the historical analysis offers to the present problem.

\section{Acknowledgements}

This article is part of $\mathrm{PhD}$ research progress by Salma Begum. In this process, I would like to express my sincere appreciation to Prof. Bruno De Meulder for his helpful critics. Sincere admiration to Jeroen Stevens for his insight and technical coordination during the study on this research. I would like to offer sincere gratitude to the Government of the People's Republic of Bangladesh for granting me the Prime Minister Fellowship to explore my research potential and pursue a Ph.D. in KU Leuven, Belgium.

\section{Conflict of Interests}

The Author declares no conflict of interest.

\section{REFERENCES}

[1] Akter, J., Sarker, M., Popescu, I., \& Roelvink, D. (2016). Evolution of the Bengal Delta and Its Prevailing Processes. Journal of Coastal Research, 32(5). doi:10.2112/JCOASTR ES-D-14-00232.1.

[2] Ashraf, K. K. (2012). Designing Dhaka: A Manifesto for a Better City. Dhaka: Loka press. 
[3] Ashraf, K. K. (2018, April). Public space makes a city. the Daily Star. Retrieved March 25, 2019, from https://www.thedailystar.net/in-focus/news/public-space-m akes-city-1653046.

[4] Ahmed, S. U. (2009). DHAKA PAST PRESENT FUTURE (2nd ed.). Dhaka, Bangladesh: Asiatic Society of Bangladesh.

[5] Ahmed, S.U., \& Mohuya, F. (2013). GROWTH AND DEVELOPMENT OF DHAKA NORTH: 1971-2011. Journal of the Asiatic Society of Bangladesh (Hum.), 58(2), 303-334.

[6] Alam, S. A., Meenar, M., \& Alam, A. (2019). Designing a Blue-Green Infrastructure (BGI) Network: Toward Water-Sensitive Urban Growth Planning in Dhaka, Bangladesh. Land, 8(9), 138. https://doi.org/10.3390/land8 090138.

[7] Begum, S. (2018). The Changing Scenarios of Public Open Space in a British Colonial City: The Case of the Ramna Area, Dhaka. Nakhara : Journal of Environmental Design and Planning, 14(1), 39-56.

[8] Dani, A. H. (2009). Dhaka: A record of its changing fortunes (A. M. Chowdhury, Ed.). Dhaka: Asiatic Society of Bangladesh.

[9] Eaton, R. M. (1996). The rise of Islam and the Bengal frontier, 1204-1760. University of California Press.

[10] Hossain, G. M. (2019). Water and architecture: The process of design myths and integrated image of Dhaka City in the primordial time. International Journal for Research in Applied Science and Engineering Technology, 7(5), 2317-2338. https://doi.org/10.22214/ijraset.2019.5386

[11] Hossain, M. S. (2013). Strategies to integrate the Mughal settlements in old Dhaka. Frontiers of Architectural Research, 2(4), 420-434. https://doi.org/10.1016/j.foar.2013 .08 .002

[12] Iqbal, I. (2010). The Bengal Delta: Ecology, State and Social Change 1840-1953 (pp. 1-20). Palgrave Macmillan.

[13] Iqbal, I. (2013). First Master Plan for Dhaka City: An Environmental Exploration. edoc-Server Home. https://edoc.huberlin.de/bitstream/handle/18452/9110/42.pd $\mathrm{f}$ ? isAllowed $=\mathrm{y} \&$ sequence $=1$
[14] Islam, M. A., Ahmed, S. U., \& Rabbani, A. K.M.G. (2010), Environment of capital Dhaka: Plants, wildlife, gardens, parks, open spaces, air, water, earthquake. Dhaka: Asiatic Society of Bangladesh.

[15] Islam, M. S., Rahman, M. R., M. Shahabuddin, A. K., \& Ahmed, R. (2010). Changes in wetlands in Dhaka City: Trends and physico-environmental consequences. J. Life Earth Sci, 5, 37-42. DOI: 10.3329/jles.v5i0.7348

[16] Islam, S. (n.d.). Business History of Dhaka upto 1947. https://www.dhakachamber.com/storage/publications/Octob er2018/gzkglBHsAaYwqlUybwD7.pdf

[17] Islam, S. N. (2016). Deltaic floodplains development and wetland ecosystems management in the GangesBrahmaputra-Meghna rivers delta in Bangladesh. Sustainable Water Resources Management, 2(3), 237-256. https://doi.org/10.1007/s40899-016-0047-6

[18] Kabir, A., \& Parolin, B. (2012). PLANNING AND DEVELOPMENT OF DHAKA - A STORY OF 400 YEARS [Conference session]. 15th INTERNATIONAL PLANNING HISTORY SOCIETY CONFERENCE, Sao Paulo.

[19] Mowla, Q.A. (2016). Colonial Spatial Planning versus Local Tradition in the Morphology of Urban Dhaka. In Rahman, M (Eds.), Dhaka: An Urban Reader (pp.01-28). Dhaka: The University Press Limited.

[20] Rahman, M. (2012). City of an architect (pp. 11-60). Dhaka: Delvistaa foundation.

[21] Rahman, M., \& Ara, Yasmin. (2016). Re structuring Dhaka through Water Urbanism: Visions, Challenges and Prospects. In Rahman, $\mathrm{M}$ (Eds.), Dhaka: An Urban Reader (pp.195-222). Dhaka: The University Press Limited.

[22] Rahman, M., Zaman, K. B., \& Hafiz, R. (2016). Translating text into space for mapping the past territory of a city: A study on spatial development of Dhaka during mughal period. City, Territory and Architecture, 3(1). https://doi.org/10.1186/s40410-016-0036-y

[23] Taylor, J. (1840). A Sketch of the Topography \& Statistics of Dacca. Calcutta: Military Orphan Press.

[24] Tilley, C. (1997). A phenomenology of landscape: Places, paths and monuments. Bloomsbury Academic. 